\title{
An overview of Bebryce (Cnidaria, Octocorallia, Plexauridae) species with tiny rosettes, with the description of a new species from the Gulf of Oman
}

\author{
Kaveh SAMIMI NAMIN \\ Netherlands Centre for Biodiversity Naturalis, \\ P.O. Box 9517, NL-2300 RA Leiden (The Netherlands) \\ and Iranian National Institute for Oceanography, \\ P.O. Box 14155-4181, 1411813389 Tehran (Iran) \\ kaveh_s_n@yahoo.com \\ Leen P. VAN OFWEGEN \\ Netherlands Centre for Biodiversity Naturalis, \\ P.O. Box 9517, NL-2300 RA Leiden (The Netherlands) \\ ofwegen@naturalis.nnm.nl
}

\footnotetext{
KEY WORDS

Coelenterata, Cnidaria, Octocorallia, Alcyonacea, Plexauridae, Bebryce, benthos, Gulf of Oman, new species.
}

MOTS CLÉS

Coelenterata, Cnidaria,

Octocorallia,

Alcyonacea,

Plexauridae, Bebryce,

Golfe d'Oman, espèce nouvelle.
Samimi Namin K. \& van Ofwegen L. P. 2010. - An overview of Bebryce (Cnidaria, Octocorallia, Plexauridae) species with tiny rosettes, with the description of a new species from the Gulf of Oman. Zoosystema 32 (3): 479-493.

\section{ABSTRACT}

A new species of Bebryce Philippi, 1842 from the Gulf of Oman is described and figured, $B$. inermis n. sp. It is characterized by having tiny rosettes $(<0.05 \mathrm{~mm}$ long) with convex surface in the surface layer of the coenenchyme, it is compared with the only four other species of Bebryce having such small rosettes, B. boninensis Aurivillius, 1931, B. cinerea Deichmann, 1936, B. stellata Hentschel, 1903 and B. studeri Whitelegge, 1897. Sclerites of B. studeri are also presented, and newly collected specimens identified as $B$. stellata are also described and figured.

\section{RÉSUMÉ}

Une vue d'ensemble des espèces de Bebryce (Cnidaria, Octocorallia, Plexauridae) avec des rosettes minuscules, et description d'une nouvelle espèce du Golfe d'Oman.

Une nouvelle espèce de Bebryce Philippi, 1842 du Golfe d'Oman est décrite et représentée, $B$. inermis $n$. sp. Elle est caractérisée par la présence de très petites rosettes $(<0,05 \mathrm{~mm}$ de longueur) avec la surface convexe dans la couche de surface du coenenchyme, elle est comparée aux quatre seules autres espèces de Bebryce ayant de telles rosettes, B. boninensis Aurivillius, 1931, B. cinerea Deichmann, 1936, B. stellata Hentschel, 1903 et B. studeri Whitelegge, 1897. Des sclérites de B. studeri sont aussi présentés et des exemplaires nouvellement collectés, identifiés comme $B$. stellata, sont aussi décrits et représentés. 


\section{INTRODUCTION}

More than 20 species of Bebryce Philippi, 1842 have been described so far, occurring both in Atlantic and in Indo-Pacific oceans. The genus is characterized by two types of sclerites, rosettes in the surface layer, and stellate plates in the subsurface layer. On examining material collected in the Gulf of Oman we found a species of Bebryce with remarkably small rosettes with a convex surface. Grasshoff (1999) was the latest author to discuss species of Bebryce with such tiny sclerites. He identified a specimen from New Caledonian waters as $B$. studeri Whitelegge, 1897 , a species originally described from Funafuti and characterized by having tiny rosettes. A further literature search showed three more species with similar shaped and sized rosettes, B. stellata Hentschel, 1903, from Ambon, Indonesia, B. boninensis Aurivillius, 1931, from the Bonin islands, Japan, and B. cinerea Deichmann, 1936, from the Caribbean (see Figure 1 for localities of the Indo-Pacific species). Of these we consider $B$. cinerea irrelevant to the present material as it was described from the western Atlantic. Bebryce boninensis clearly differs in totally lacking spindles with an unilateral projection (Aurivillius 1931: 200), which are often present around the calyx margin in other species of Bebryce. The description of $B$. studeri was based on a small fragment of only $6 \mathrm{~cm}$ long stored in formalin (Whitelegge 1897: 314, $315)$, and of the type specimen of B. stellata only $1 \mathrm{~cm}$ is left. Therefore we compared the Gulf of Oman specimens with recently collected material we regard representing $B$. studeri and B. stellata. Of both these species we depict sclerites and the B. stellata specimens are described. We consider the present material sufficiently different to describe it as a new species, $B$. inermis $\mathrm{n}$. sp.

\section{MATERIALS AND METHODS}

Material was collected by the first author through SCUBA diving off Muscat, Oman, in 2007 and 2009. The holotype of $B$. inermis $\mathrm{n}$. sp. is deposited in MNHN, and paratypes are deposited in RMNH. All material is preserved in $70 \%$ alcohol.
ABBREVIATIONS

MNHN Muséum national d'Histoire naturelle, Paris; ORSTOM former acronym of IRD - Institut de recherche pour le développement, Paris;

RMNH Netherlands Centre for Biodiversity Naturalis, formerly Rijksmuseum van Natuurlijke Historie, Leiden.

\section{SYSTEMATICS}

Class ANTHOZOA Ehrenberg, 1831 Subclass OCTOCORALLIA Haeckel, 1866 Order ALCYONACEA Lamouroux, 1812

Family PleXaURIDAe Gray, 1859

Genus Bebryce Philippi, 1842

\section{Bebryce inermis $\mathrm{n}$. sp.}

(Figs 1; 2A, B; 3-7)

Type Material. - Holotype: Oman. 2331'38.92”N, $58^{\circ} 44^{\prime 2} 23.32 ”$, coll. K. Samimi Namin, 1.XII.2007, 1 colony (MNHN).

Paratypes: Oman. 2331'48.88”N, 5843'40.89”E, coll. K. Samimi Namin, XI.2007, 1 colony (RMNH Coel. 38923). - 2331'23.73”N, 5844'50.58”E, coll. K. Samimi Namin, 30.XI.2007, 3 colonies (RMNH Coel. 38924). - 2331'48.88”N, 5843'40.89”'E, coll. K. Samimi Namin, 19.V.2009, 4 colonies (RMNH Coel. 38925). - Daymaniyat islands, $23^{\circ} 50^{\prime} 20.85^{\prime \prime} \mathrm{N}$, $57^{\circ} 58^{\prime} 11.19$ ”'E, coll. K. Samimi Namin, 5 colonies (RMNH Coel. 39556). - Bandar Al-Khiran, 2331'38.92”N, 5844'23.32”'E, 3 colonies (RMNH Coel. 39557). Daymaniyat islands, $23^{\circ} 51^{\prime} 42.96$ ”N, 58 07'10.15”E, coll. K. Samimi Namin, 27.V.2009, 4 colonies (RMNH Coel. 39558). — 2332'1.80”N, 5842'54.06”'E, coll. K. Samimi Namin, 8.VI.2009, 1 colony (RMNH Coel. 39559).

ETYMology. - Latin "inermis", unarmed, without weapons, defenceless, toothless, without a sting, refers to the calyx margin spindles without split antler-like projection.

\section{DESCRIPTION}

The holotype is fan-shaped without anastomoses. The colony is $6.5 \mathrm{~cm}$ high and $7 \mathrm{~cm}$ wide, the main stem is about $2 \mathrm{~mm}$ wide and branching starts at the base of the main stem (Fig. 2A). Polyps are situated all around the branches with prominent calyces about $1 \mathrm{~mm}$ high. Some parts of the colony, mostly at the base, are covered with an encrusting sponge.

Polyps are retracted and have 3-6 spindles per 


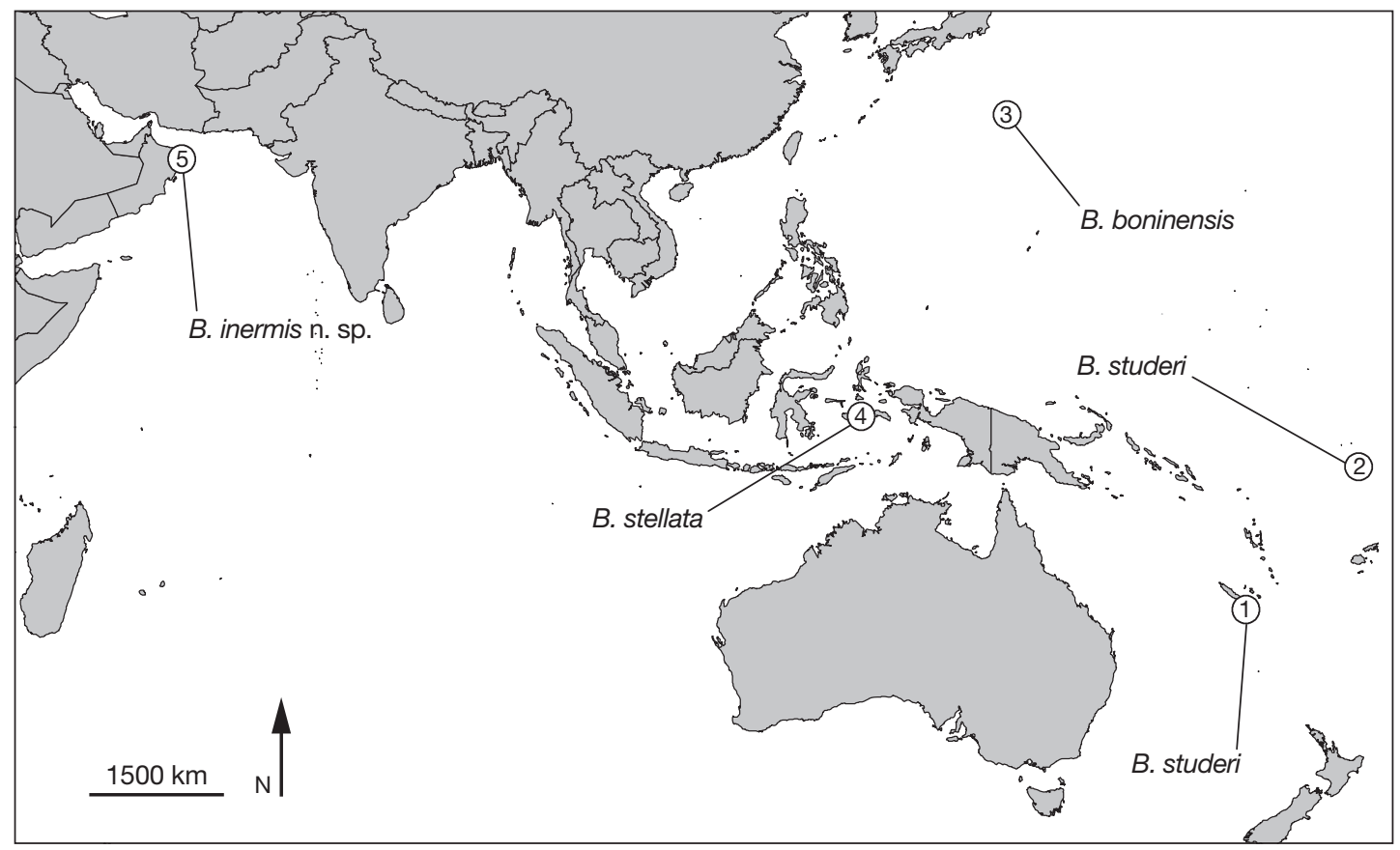

FIG. 1. - Localities of the Bebryce Philippi, 1842 species with tiny rosettes: 1, New Caledonia; 2, Funafuti; 3, Bonin islands, Japan; 4, Ambon, Indonesia; 5, Oman.

point. These spindles are up to $0.35 \mathrm{~mm}$ long and have spines or a spiny leaf at their distal end (Fig. 4A). The collaret has 2 or 3 rows of bent spindles, up to $0.40 \mathrm{~mm}$ long (Fig. 4B). Tentacles have bow-shaped spindles up to $0.07 \mathrm{~mm}$ long, and a few small rods, up to $0.05 \mathrm{~mm}$ long.

At the margin of the calyces spindles are present, up to $0.12 \mathrm{~mm}$ long, with an unilateral projection (Fig. 4C).

The surface layer sclerites are rosettes, up to $0.05 \mathrm{~mm}$ long, with warty, rounded, or bristle-like projections (Fig. 4D-F).

In the subsurface layer a few rosettes occur, up to $0.12 \mathrm{~mm}$ long (Fig. 5A). Most sclerites are stellate plates, up to $0.18 \mathrm{~mm}$ long (Fig. 5B). Furthermore, several less developed sclerites are also present (Fig. 5C).

\section{Colour}

Live colonies were brown-yellowish in colour with yellow polyps (Fig. 3); preserved it is brown, sclerites colourless.

\section{VARIABILITY}

Several paratypes have a bushy colony shape (Fig. 2B). Also the sclerites differ between colonies, in about half of the paratypes the stellate plates with long rays are few in number; also the number of rosettes with bristle-like projections is much smaller in these specimens (Figs 6; 7). Very little is known about sclerite characters to use for identification of Bebryce species. At present we consider these observed differences to represent intra-specific variation rather than describing two related species.

\section{HABITAT}

Most of the specimens can be seen in dark places such as cracks and caverns on underwater cliffs and walls, often hanging down. We observed all collected specimens to be overgrown by sponges on some parts of the colony.

\section{REMARKS}

For comparison with B. studeri we used the material described by Grasshoff (1999): ORSTOM HG 


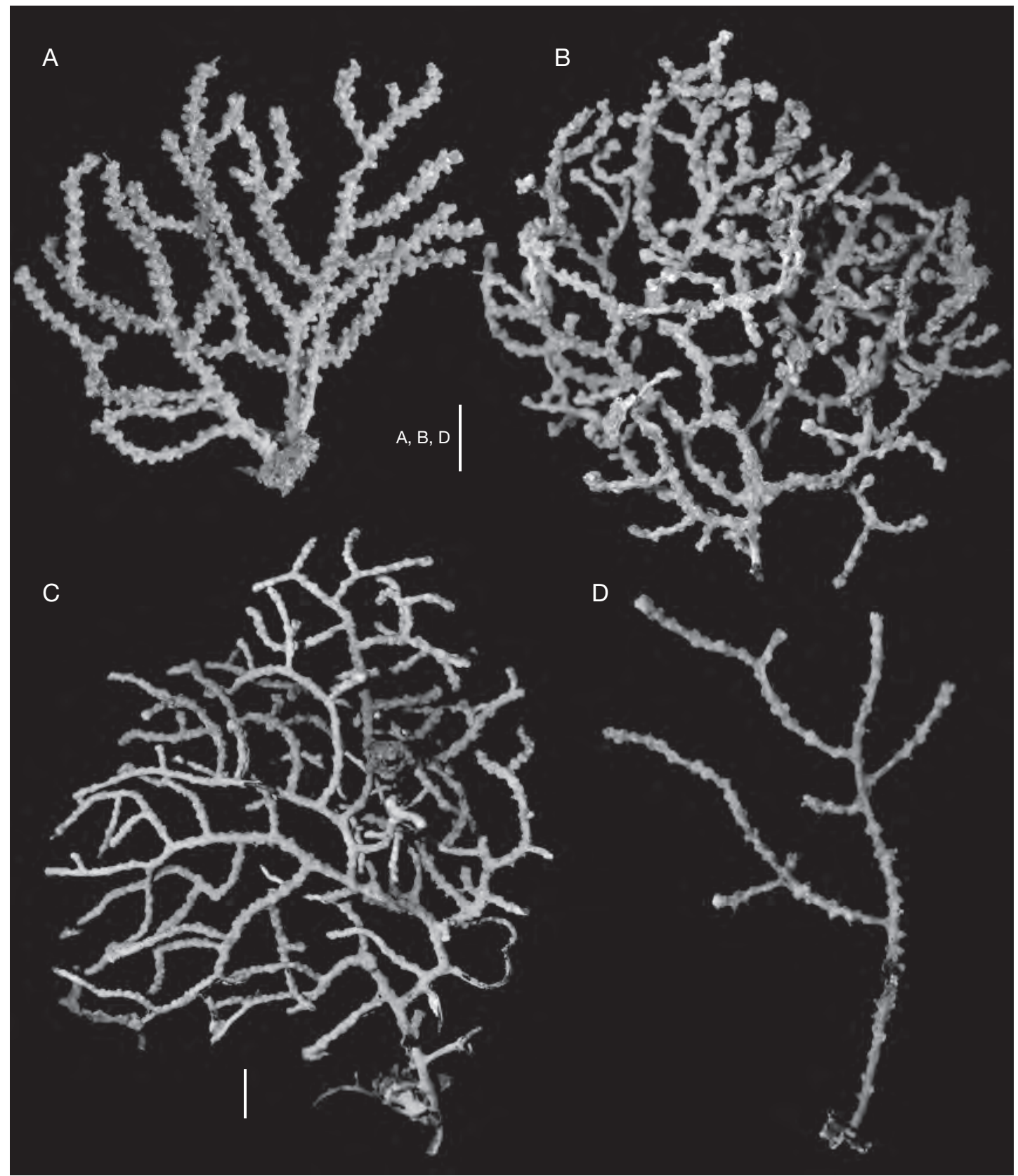

FIG. 2. - A, B, Bebryce inermis n. sp.; A, holotype (MNHN); B, paratype (RMNH Coel. 38924); C, D, Bebryce stellata (RMNH Coel. 39560). Scale bars: $10 \mathrm{~mm}$.

200, New Caledonia, S lagon, Îlot Canard, stn 136, 23 m depth; material stored in the MNHN (under MNHN-Oct.0000-0569). Bebryce studeri differs from B. inermis $\mathrm{n}$. sp. in having different calyx margin spindles, with a split projection (Fig. 8C), almost antler-like. Additionally, it lacks poorly 

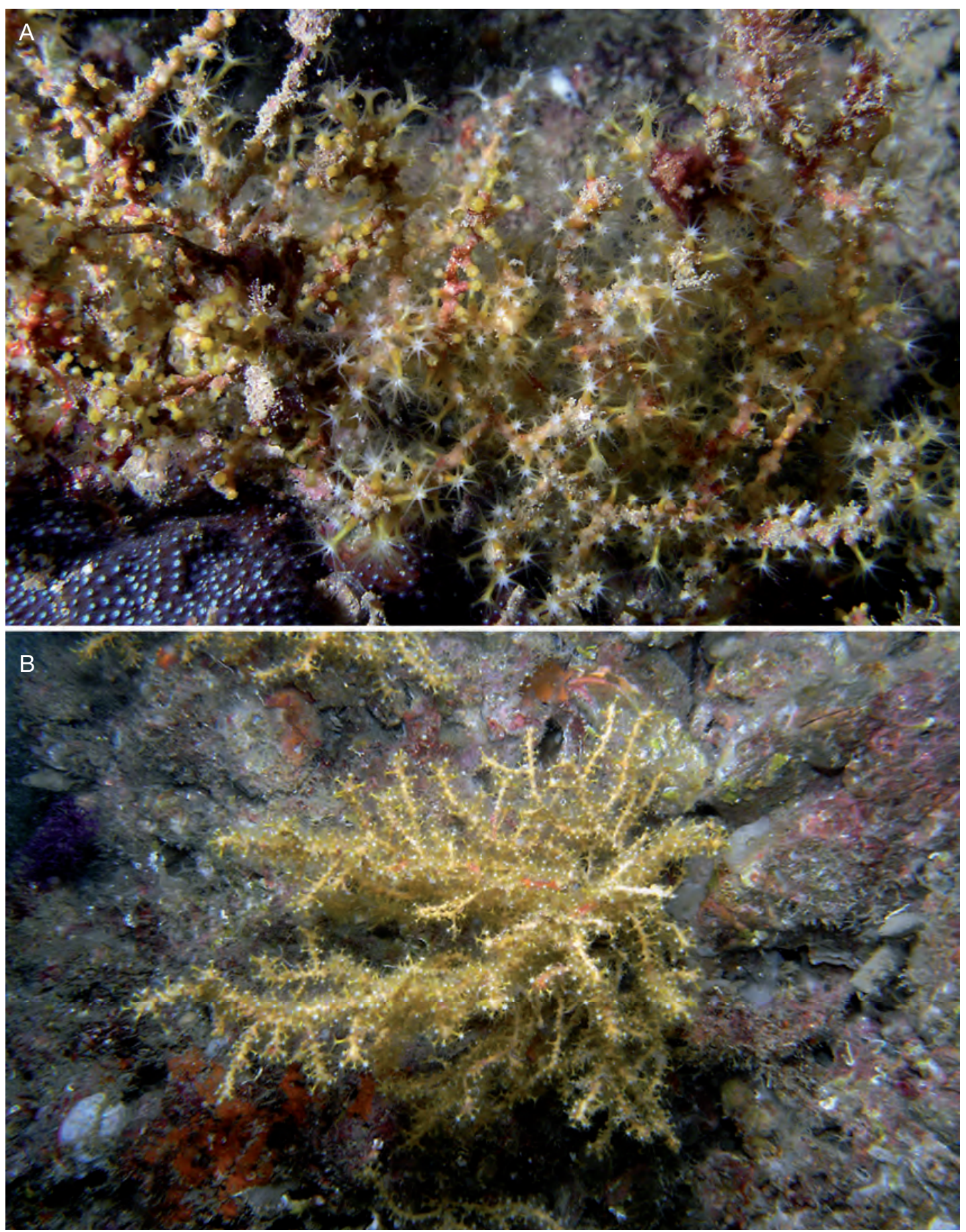

FIG. 3. - Live colonies of Bebryce inermis n. sp.: A, a colony with extended polyps, overgrown by sponges on some parts; B, a colony hanging from a rocky underwater cliff. Photos: M. Claereboudt. 


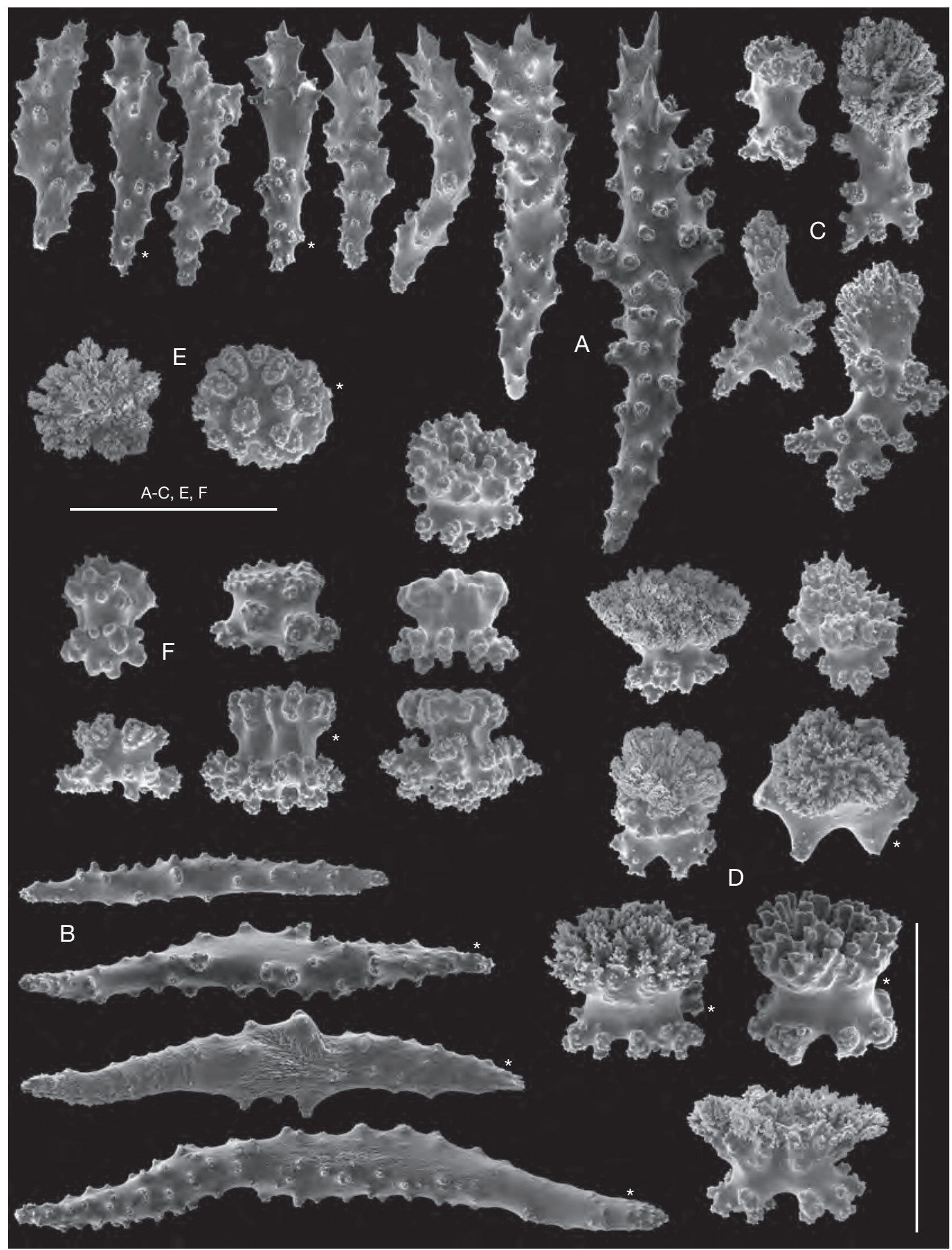

FIG. 4. - Bebryce inermis n. sp., holotype (MNHN) and paratype ( ${ }^{*}$, RMNH Coel. 38924): A, point sclerites; B, collaret spindles; $\mathbf{C}$, sclerites of calyx margin; $\mathbf{D}-\mathbf{F}$, rosettes of surface layer; $\mathbf{E}$, top views. Scale bars: $0.10 \mathrm{~mm}$. 


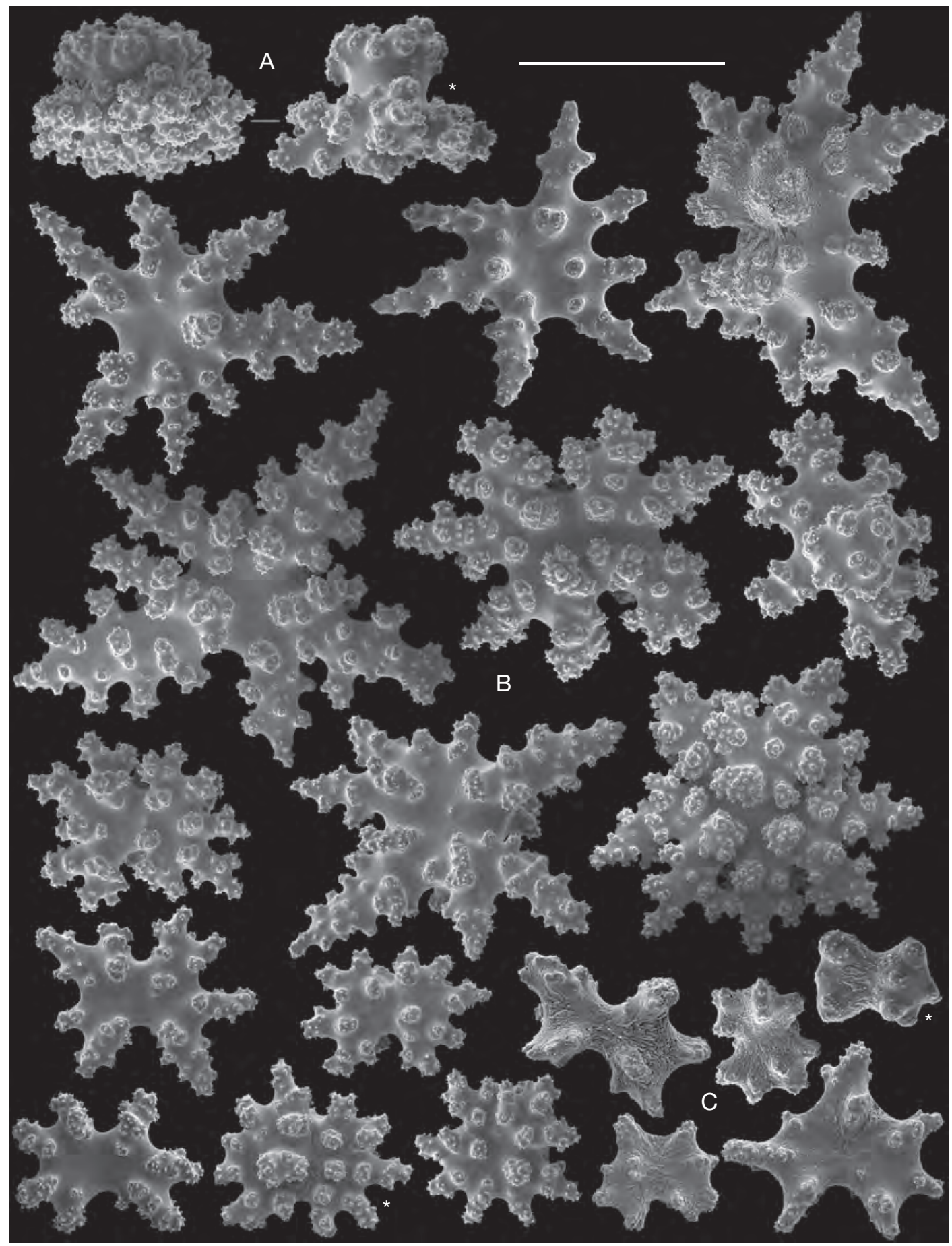

FIG. 5. - Bebryce inermis n. sp., holotype (MNHN) and paratype ( ${ }^{*}$, RMNH Coel. 38924): A, rosettes of surface layer; $\mathbf{B}$, stellate plates of subsurface layer; $\mathbf{C}$, less developed sclerites of subsurface layer. Scale bar: $0.10 \mathrm{~mm}$. 


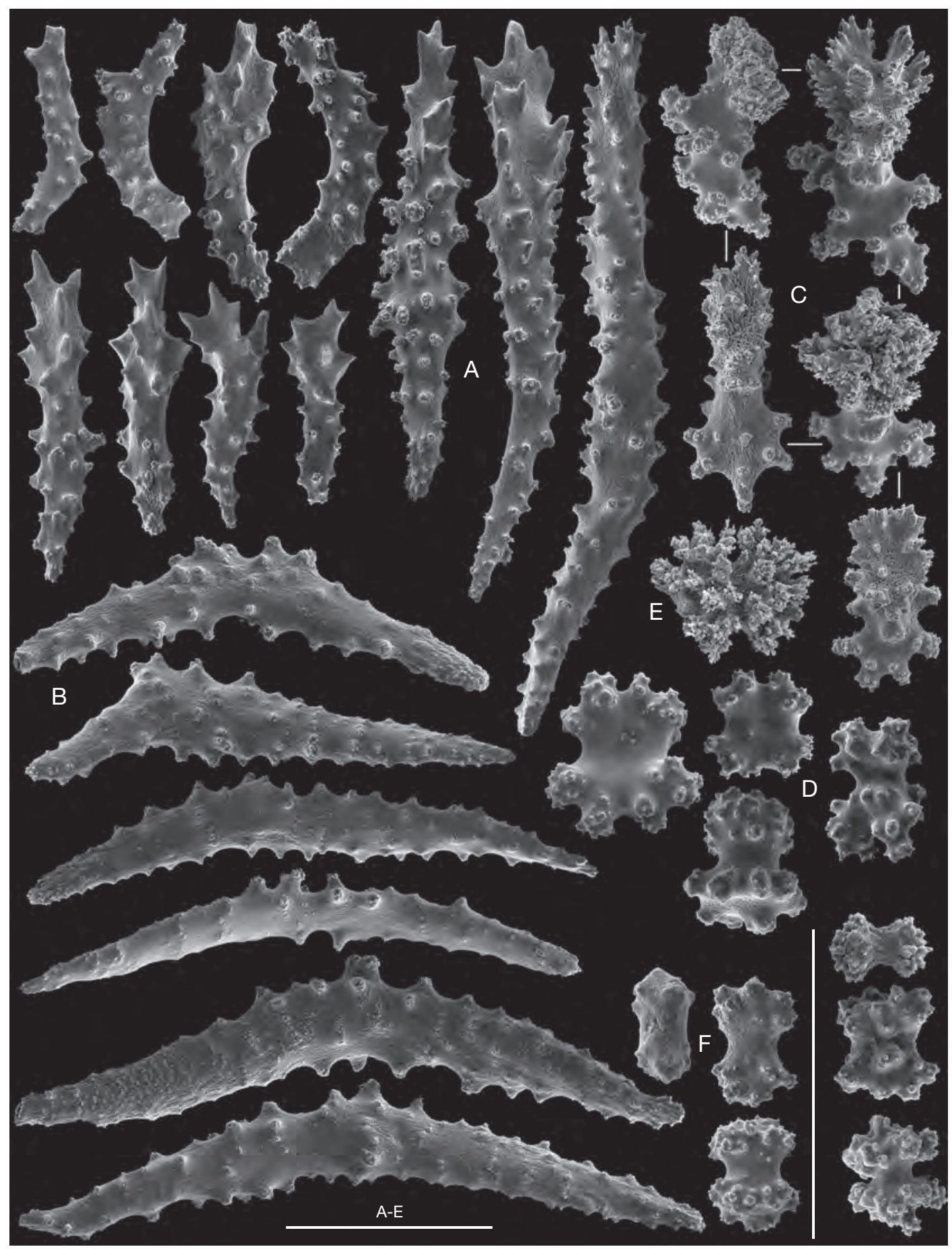

FIG. 6. - Bebryce inermis n. sp., paratype (RMNH Coel. 39557): A, point sclerites; B, collaret spindles; C, sclerites of calyx margin; D-F, rosettes of surface layer; E, top view. Scale bars: $0.10 \mathrm{~mm}$. 


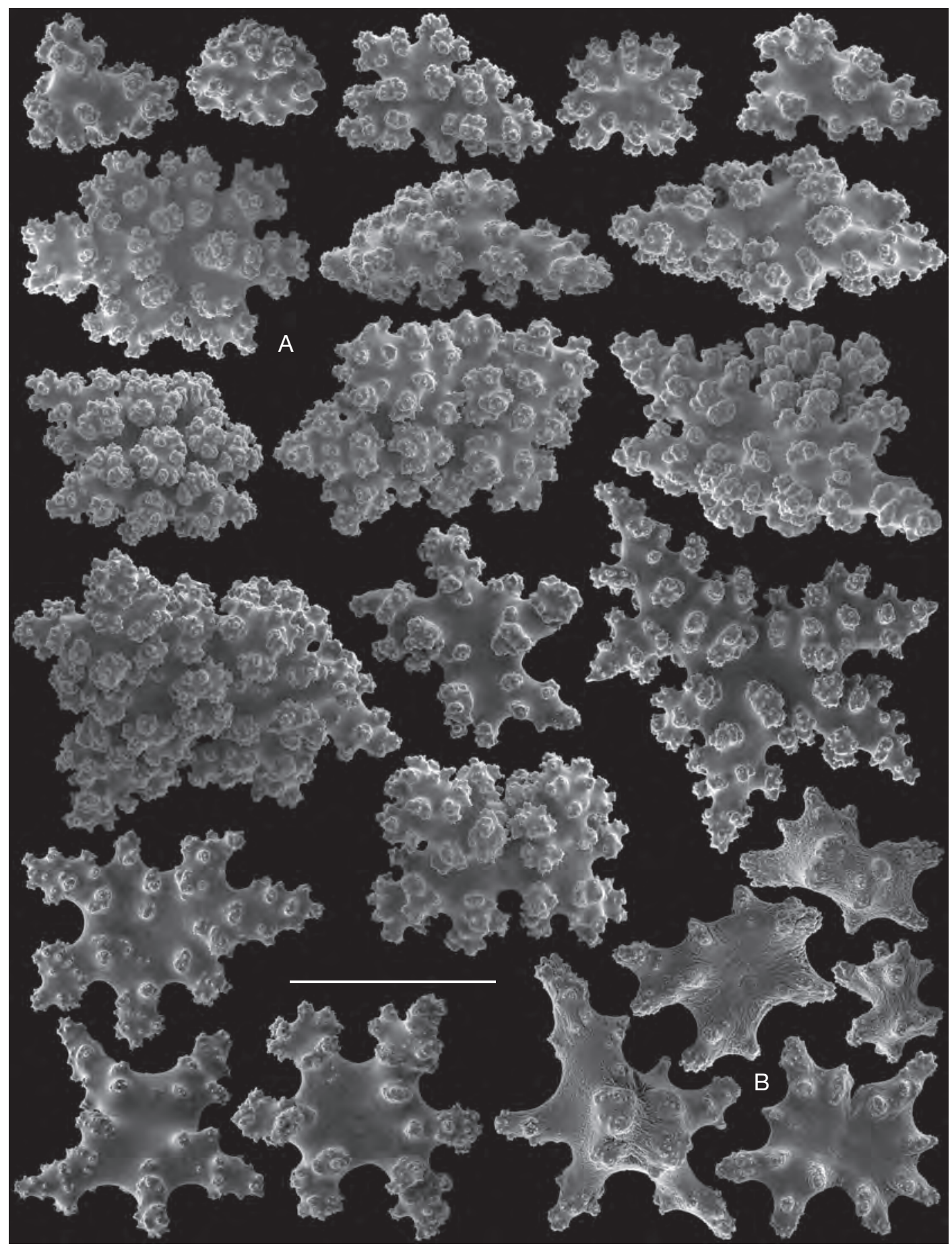

FIG. 7. - Bebryce inermis n. sp., paratype (RMNH Coel. 39557): A, stellate plates of subsurface layer; B, less developed sclerites of subsurface layer. Scale bar: $0.10 \mathrm{~mm}$. 


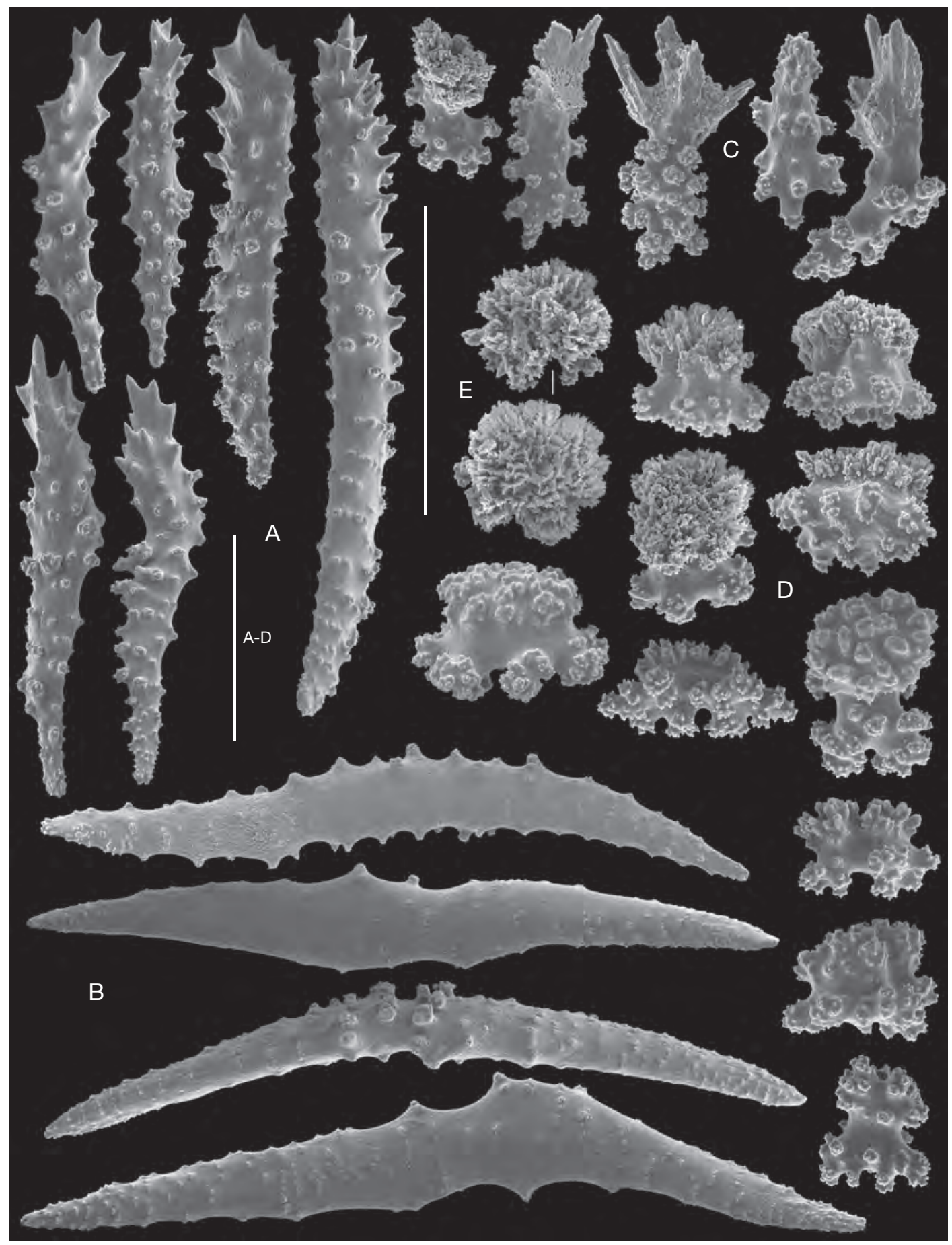

FIG. 8. - Bebryce studeri Whitelegge, 1897 (MNHN-Oct.0000-0569): A, point sclerites; B, collaret spindles; C, sclerites of calyx margin; D, E, rosettes of surface layer; E, top views. Scale bars: $0.10 \mathrm{~mm}$. 


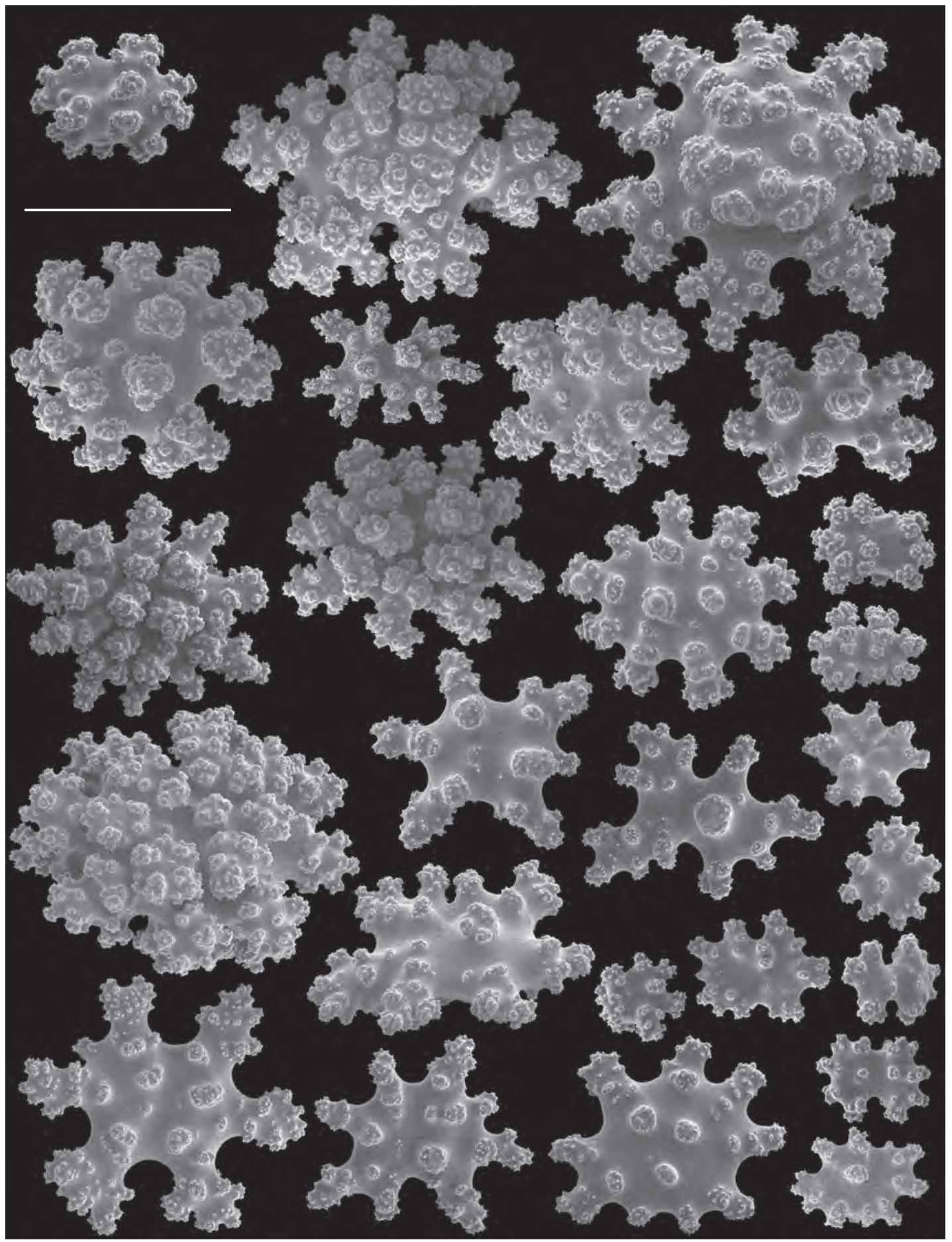

FIG. 9. - Bebryce studeri Whitelegge, 1897 (MNHN-Oct.0000-0569), stellate plates of subsurface layer. Scale bar: $0.10 \mathrm{~mm}$. 
developed subsurface sclerites (Fig. 9). For further comparison we also present polyp sclerites and rosettes of $B$. studeri (Fig. 8A, B, D, E).

For comparison with $B$. stellata we used RMNH material from the type locality Ambon, collected during the 1996 LIPI-NNM Fauna Malesiana Maluku Expedition. Bebryce stellata differs from $B$. inermis n. sp. and B. studeri in having many ellipsoids in the subsurface layer.

Two colonies of RMNH Coel. 39558 have several small colonies of an unknown Astrogorgia Verrill, 1868 species attached to the branches.

Bebryce stellata Hentschel, 1903

(Figs $1 ; 2 \mathrm{C}, \mathrm{D} ; 10 ; 11$ )

Bebryce stellata Hentschel, 1903: 649, pl. 53 figs 22-25.

Material eXAmineD. - Indonesia. Ambon, stn MAL.12, $\mathrm{N}$ coast near Morela, $03^{\circ} 33^{\prime} \mathrm{S}, 128^{\circ} 12^{\prime} \mathrm{E}$, reef flat, small lagoon, sea grass, calcareous rock with many corals, steep slope with stony and soft corals, hand collecting, diving, 13/14.XI.1996, 2 colonies and 2 microscope slides (RMNH Coel. 39560).

\section{DESCRIPTION}

The largest colony of RMNH Coel. 39560, is fan-shaped without anastomoses. It is $12 \mathrm{~cm}$ high and $11 \mathrm{~cm}$ wide, the main stem is about $2 \mathrm{~mm}$ wide and branching starts at the base of the main stem (Fig. 2C). The smaller colony is sparsely branched, $8.5 \mathrm{~cm}$ high, and $5.5 \mathrm{~cm}$ wide (Fig. 2D). In both colonies the polyps are situated all around the branches with prominent calyces about $0.5 \mathrm{~mm}$ high. Some parts of the colony, mostly at the base, are covered with an encrusting sponge. The sclerite description is based on the larger colony.

Polyps are retracted and have 4 spindles per point. These spindles are up to $0.40 \mathrm{~mm}$ long and have spines or a spiny leaf at their distal end (Fig. 10A). The collaret has 4 rows of bent spindles, up to $0.55 \mathrm{~mm}$ long (Fig. 10B). Tentacles have bowshaped spindles up to $0.12 \mathrm{~mm}$ long (Fig. 10C), and a few rods, up to $0.06 \mathrm{~mm}$ long.

At the margin of the calyces spindles are present, up to $0.12 \mathrm{~mm}$ long, with an unilateral projection (Fig. 10D).
The surface layer sclerites are rosettes, up to $0.07 \mathrm{~mm}$ long, with warty, rounded, or bristle-like projections (Fig. 10E).

In the subsurface layer the sclerites are stellate plates, up to $0.16 \mathrm{~mm}$ long (Fig. 11), most of them forming ellipsoid bodies.

\section{Colour}

Preserved colonies whitish, sclerites colourless.

\section{REMARKS}

The holotype of Bebryce stellata is present in the Musée zoologique de Strasbourg, France (MSZ NS 101), but only $1 \mathrm{~cm}$ remained of the originally $4.5 \mathrm{~cm}$ long fragment, and it was not available for re-examination.

The description of Hentschel (1903) is very unsatisfactory and the magnifications of sclerites in his plate do not correspond with his measurements in the description. He presented two measurements in his description, stellate plates up to $0.04 \mathrm{~mm}$ long, and polyp sclerites up to $0.44 \mathrm{~mm}$ long. Hentschel mentioned "Von der seite gesehen erscheinten die kleiner spicula oft knopfförmig"; these are the rosettes typical for Bebryce, and therefore we conclude $B$. stellata must have tiny rosettes like the other species under study.

Despite this unsatisfactory description of Hentschel and the impossibility to re-examine the type specimen we identified the Ambon material as $B$. stellata because of the following:

1) both our material and the type specimen of $B$. stellata were found at Ambon, Indonesia;

2) Hentschel (1903) described "Grosse und alte Kalkkörper verlieren die klare Sternform und werden zu unregelmässigen, stark warzigen Klumpen”, these are the ellipsoid sclerites so common in our material, and not so dominantly present in most Bebryce species;

3) a few of the rosettes depicted by us are in complete agreement with those given by Hentschel (1903: plate 53, fig. 24); the same applies for the stellate plates; 4) in total, eight specimens belonging to Bebryce were found around Ambon during the Fauna Malesiana Maluku Expedition, the six not yet identified specimens differ greatly from B. stellata, in having much thicker branches and much larger rosettes. 


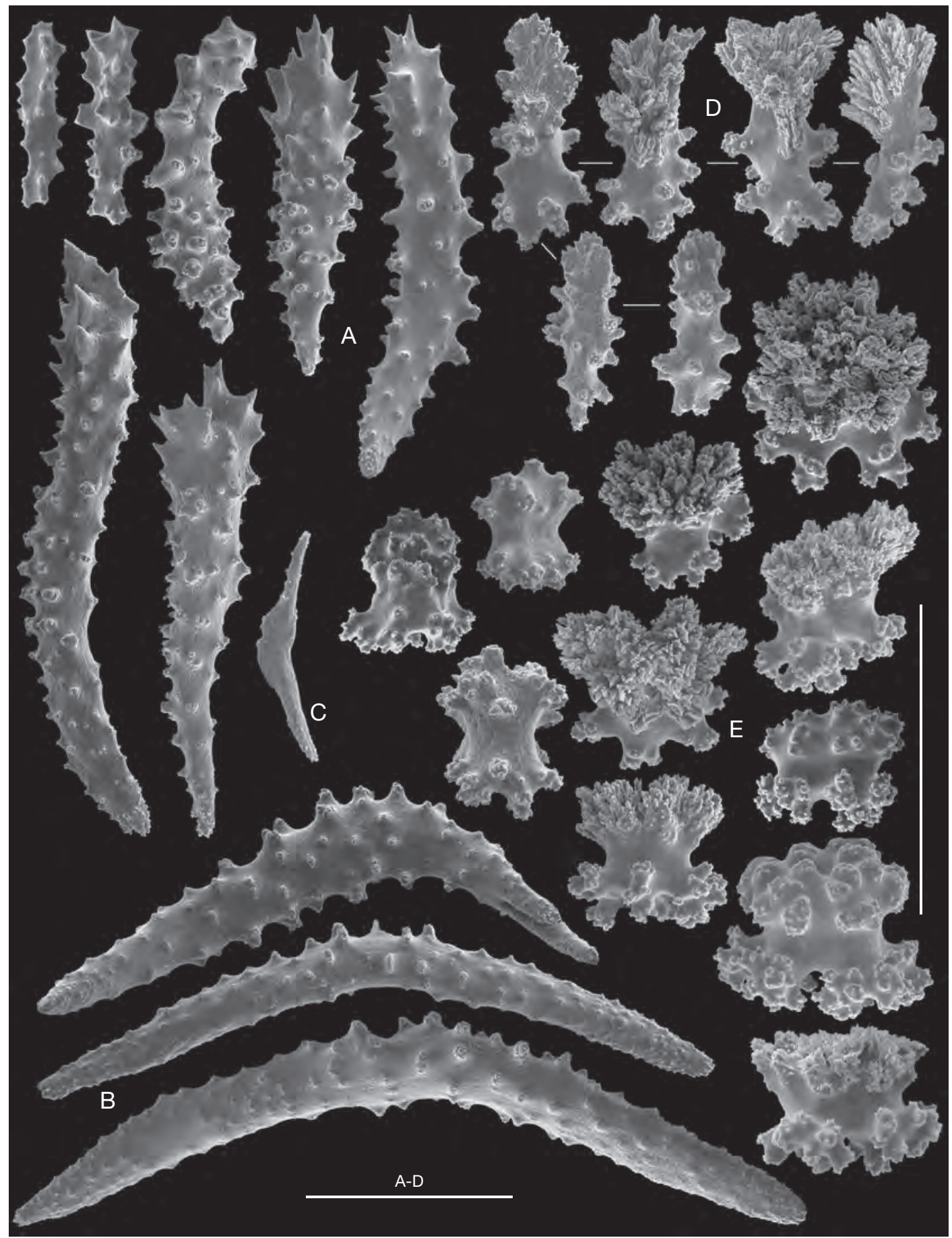

FIG. 10. - Bebryce stellata Hentschel, 1903 (RMNH Coel. 39560): A, point sclerites; B, collaret spindles; C, tentacle rod; D, sclerites of calyx margin; $\mathbf{E}$, rosettes of surface layer. Scale bars: $0.10 \mathrm{~mm}$. 


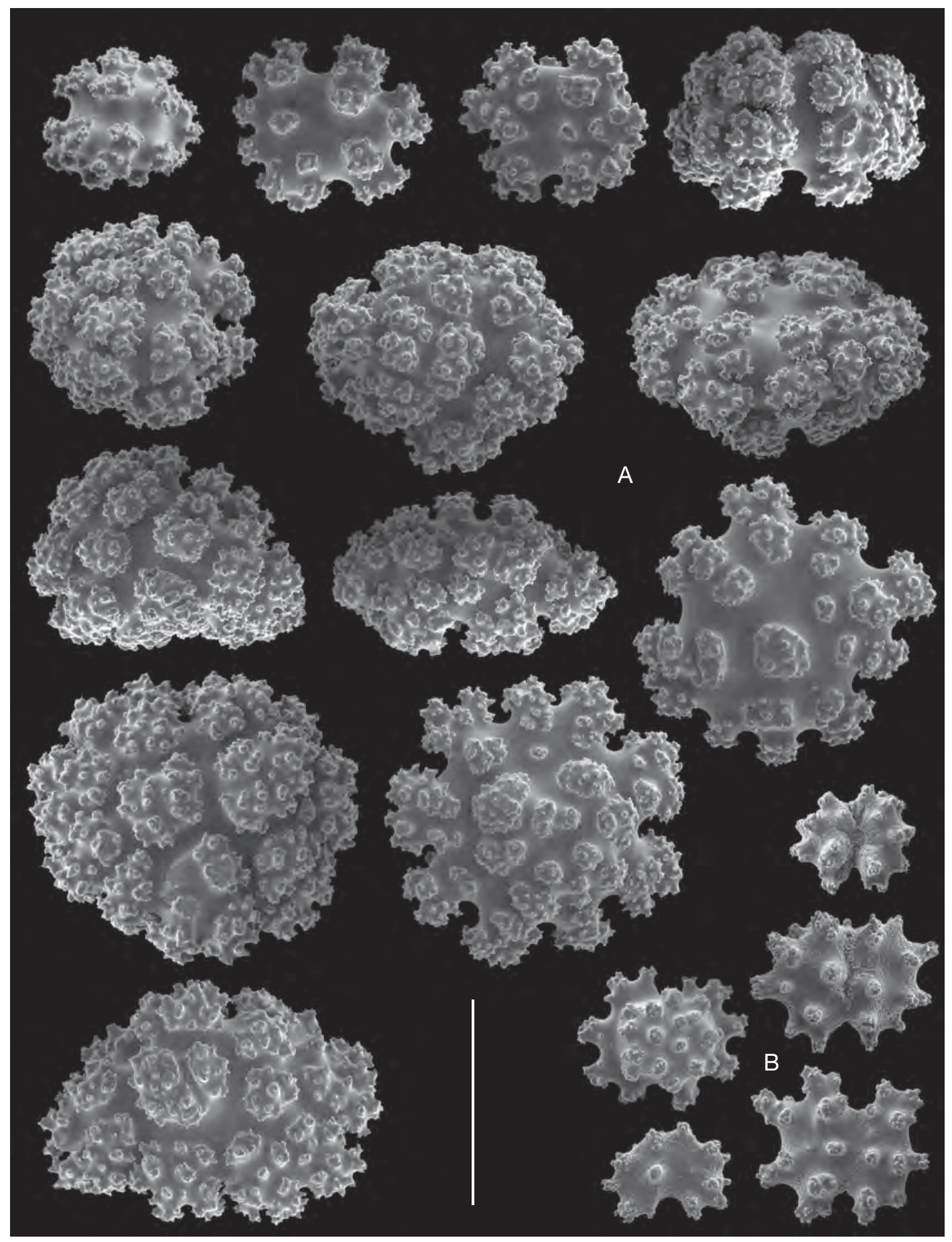

FIG. 11. - Bebryce stellata Hentschel, 1903 (RMNH Coel. 39560): A, stellate plates of subsurface layer; B, less developed sclerites of subsurface layer. Scale bar: $0.10 \mathrm{~mm}$. 


\section{Acknowledgements}

We would like to thank Elisabeth Ludes-Fraulob (Musée zoologique de Strasbourg, France) for information about the condition of the type specimen of Bebryce stellata, and Aude Andouche (MNHN) for use of a fragment of B. studeri. Mr J. van Egmond and $\mathrm{Mr}$ T. J. G. M. van Oyen (both RMNH) are thanked for curatorial assistance. M. R. Claereboudt (Sultan Qaboos University, Oman) and his family are appreciated for their hospitality and support during field trips to the first author. The first author is most grateful to A. Willson for his hospitality and useful comments as well as S. C. Wilson and all staff at Five Oceans Environmental Services LLC, Muscat, specially O. Taylor, E. Looker, D. Mothershaw, I. Benson, and F. Al-Abdali for support and accompanying in field surveys at Daymaniyat islands. The research at RMNH was supported by Martin-Fellowship to the first author. We thank P. Alderslade (CSIRO, Marine \& Atmospheric Research, Hobart) and Gary Williams (California
Academy of Sciences, San Francisco) for helpful comments on the manuscript.

\section{REFERENCES}

Aurivillius M. 1931. - The Gorgonarians from Dr. Sixten Bock's expedition to Japan and Bonin Islands 1914. Kungliga Svenska vetenskapsakademiens handlingar 3 (9) 4: 1-337.

GRASSHOFF M. 1999. - The shallow water gorgonians of New Caledonia and adjacent islands (Coelenterata: Octocorallia). Senckenbergiana biologica 78 (1/2): $1-245$.

Hentschel E. 1903. - Gorgonacea von Amboina und Thursday Island. Zoologische Forschungsreisen in Australien und dem Malayischen Archipel. Ausgefuhrt in den Jahren 1891-1893 von Richard Semon, 5. Band, 6. Lieferung. Denkschriften der Medizinisch-naturwissenschaftlichen Gesellschaft zu Jena: 643-652.

WhitelegGe T. 1897. - The Alcyonaria of Funafuti. Part II. Memoirs of the Australian Museum 3(5): 307320.

Submitted on 28 December 2009; accepted on 6 May 2010. 